\title{
PERBEDAAN LAJU ALIRAN SALIVA TERSTIMULASI ANTARA PENGUNYAHAN PARAFIN WAX DENGAN PERMEN KARET XYLITOL PADA PASIEN TERINDIKASI GERD
}

Ridha Andayani*, Sunnati**, Amatu Sholiha***

\begin{tabular}{c}
\hline Keywords: \\
GERD, salivary flow \\
rate, paraffin wax, \\
xylitol gum
\end{tabular}

\section{ABSTRACT}

Background: Gastroesophageal Reflux Disease (GERD) is a condition of irreversibility (reflux) of stomach contents into the esophagus exceeds the normal amount and causes a variety of complaints. Reduction in salivary flow and decreased secretion of bicarbonate in the saliva cannot be avoided so that the patient is symptomatic GERD in the oral cavity in the form of halitosis and tooth erosion. Paraffin wax and chewing xylitol gum can be an alternative to increase the rate of saliva and neutralize the acid in patients with GERD. This study aims to observes salivary flow rate differences between paraffin wax and xylitol gum patient - indicated GERD at RSUDZA in Banda Aceh.

Method: This research is an analytic study with cross sectional approach and a subject of 17 people. Data were analyzed by statistical tests using Wilcoxon test. The results of this study, the salivary flows by chewing paraffin wax at the low category $(52.9 \%)$, whereas salivary flows by chewing xylitol gum is the normal category $(76.5 \%)$.

Result:The data obtained $P=0.001(P<0.05)$ for the difference between chewing paraffin wax and chewing xylitol gum.

Conclusion: The conclusion from this study is a significant difference between salivary flows chewing paraffin wax and chewing xylitol gum in patient-indicated GERD at RSUDZA in Banda Aceh

\section{PENDAHULUAN}

Gastroesophageal Reflux Disease (GERD) merupakan suatu keadaan patologis sebagai akibat dari berbaliknya (refluks) kandungan lambung ke esofagus melebihi jumlah normal dan menimbulkan berbagai keluhan. ${ }^{1}$ Prevalensi kejadian GERD di seluruh dunia pada orang dewasa rata-rata $11 \%$ sampai $38,8 \%$ dan berbeda di setiap negara. ${ }^{2}$ Angka kejadian GERD mengalami peningkatan di Asia; di Malaysia prevalensi GERD 2,7\% (1991-1992) menjadi 38,8\% (2004), di Singapura prevalensi GERD mencapai $10,5 \%$, sedangkan di Indonesia pendataan prevalensi GERD belum dilakukan. 3,4,5 Gastroesophageal
Reflux Disease (GERD) biasanya juga dikarakteristikan dengan rasa terbakar di dada (heartburn) dan regurgitasi. ${ }^{6}$ Regurgitasi merupakan akibat naiknya (refluks) asam lambung hingga terasa pahit di lidah. Refluks dapat menimbulkan komplikasi intraesofagus seperti striktur, Barrett's esofagus bahkan adenokarsinoma esofagus dan juga dapat mengakibatkan komplikasi ekstraesofagus seperti laringitis, batuk kronis, nyeri dada non kardiak, bronkiektasis, asma dan erosi gigi. ${ }^{7}$

Menurut penelitian Pace (2008) pada kasus erosi gigi, ditemukan $24 \%$ responden menderita GERD sedangkan pada kasus GERD ditemukan sebanyak 32,5\% responden mengalami erosi gigi. ${ }^{8}$ Erosi gigi merupakan

*Bagian Oral Biologi Fakultas Kedokteran Gigi Universitas Syiah Kuala, **Bagian Periodonsia Fakultas Kedokteran Gigi Universitas Syiah Kuala, ${ }^{* * *}$ Program Pendidikan Dokter Gigi Fakultas Kedokteran Gigi Universitas Syiah Kuala Korespondensi: : ridha_andayani@yahoo.com 
kerusakan jaringan keras gigi yang disebabkan oleh asam yang tidak melibatkan bakteri. ${ }^{9}$ Penyebab erosi gigi terbagi atas dua faktor yaitu faktor ekstrinsik dan instrinsik. ${ }^{10,11}$ Penyebab ekstrinsik erosi gigi berupa frekuensi mengkonsumsi makanan atau minuman yang asam, menggunakan produk kesehatan atau obat-obatan yang mengandung asam seperti vitamin $C$ dan aspirin serta konsumsi alkohol. ${ }^{11,12}$ Penyebab intrinsik erosi gigi seperti muntah berulang, terapi obat cytostatic dan naiknya asam lambung ke rongga mulut pada penderita GERD. ${ }^{13,14}$ Erosi pada gigi dapat terjadi ketika $\mathrm{pH}$ saliva berada dibawah 5,5 disebut dengan 'pH kritis' yang dapat memicu demineralisasi pada gigi. ${ }^{14}$

Saliva mempunyai peran yang penting di dalam rongga mulut. ${ }^{15}$ Salah satu fungsi saliva yaitu melindungi ekosistem rongga mulut dari asam yang timbul akibat faktor instrinsik dan ekstrinsik. ${ }^{10}$ Asam yang disebabkan faktor intrinsik seperti muntah berulang, terapi obat cytostatic dan naiknya asam lambung ke rongga mulut pada penderita GERD mempunyai $\mathrm{pH}$ dibawah 1 yang berada jauh di bawah $\mathrm{pH}$ kritis dan menyebabkan saliva terganggu baik dalam kualitas maupun kuantitas seperti laju aliran, $\mathrm{pH}$, dan kapasitas buffer. ${ }^{10}$

Laju aliran saliva dapat dipengaruhi oleh keadaan saliva dengan stimulasi atau tanpa stimulasi. Laju aliran saliva tanpa stimulasi yaitu $0,25-0,35 \mathrm{~mL} /$ menit dan laju aliran saliva terstimulasi $1 \mathrm{~mL} /$ menit. $^{16,17}$ Laju aliran saliva terstimulasi dapat dilakukan dengan stimulus mekanik (pengunyahan) dan stimulus kimia (pengecapan). ${ }^{17}$ Laju aliran saliva dengan stimulus mekanis dapat dilakukan dengan pengunyahan parafin wax, sedangkan untuk stimulus kimia dapat dilakukan dengan meletakkan asam sitrat $2 \%$ pada dorsum lidah yang berguna meningkatkan laju aliran saliva.
Pengunyahan permen karet xylitol merupakan kombinasi dari stimulus mekanik dan kimia yang juga dapat meningkatkan laju aliran saliva. ${ }^{18}$ Permen karet xylitol selain memberikan rasa manis juga dibuktikan secara ilmiah oleh Patel dkk (2015) bahwa pengunyahan permen karet xylitol dapat memicu mineralisasi dengan peningkatan aliran saliva dan menghambat pertumbuhan, metabolisme dan produksi polisakarida dari Streptococcus mutans. ${ }^{19}$

Pada pasien GERD yang terdapat manifestasi oral berupa erosi gigi dan halitosis secara tidak langsung mengindikasikan saliva terganggu secara kuantitas. $^{10}$ Yoshikawa dkk (2012) dalam penelitiannya menyatakan bahwa terdapat penurunan laju aliran saliva pada pasien GERD. ${ }^{20}$ Pengunyahan parafin wax dan permen karet xylitol dapat menjadi alternatif untuk meningkatkan laju saliva pada pasien GERD, menetralisir asam dan memberikan lingkungan basa yang memacu remineralisasi. ${ }^{21}$

Berdasarkan uraian di atas, peneliti tertarik ingin melakukan penelitian mengenai perbedaan laju aliran saliva terstimulasi antara pengunyahan parafin wax dengan permen karet xylitol pada pasien terindikasi GERD di RSUD dr. Zainoel Abidin Banda Aceh.

\section{METODE PENELITIAN}

Jenis penelitian ini adalah analitik dengan menggunakan desain cross sectional yaitu mengukur antar variabel dalam suatu waktu dan menentukan hubungan antara keduanya. Penelitian ini dilaksanakan di Poliklinik Gastroenterohepatologi RSUD dr. Zainoel Abidin Banda Aceh pada bulan Februari-Maret tahun 2016.

Populasi dalam penelitian ini adalah semua pasien yang mengeluhkan heartburn 
dan regurgitasi dan berobat di Poliklinik Gastroenterohepatologi RSUD dr. Zainoel Abidin Banda Aceh. Sampel dalam penelitian ini adalah pasien dengan nilai total kuisioner GERDQ berbahasa Indonesia $\geq 8$ yang berobat di Poliklinik Gastroenterohepatologi RSUD dr. Zainoel Abidin Banda Aceh pada bulan Februari-Maret 2016 yang memenuhi kriteria inklusi dan eksklusi. Pada penelitian ini digunakan metode non random sampling dengan teknik purposive sampling.

Kriteria inklusi pada penelitian ini adalah pasien dengan keluhan heartburn dan regurgitasi serta nilai total kuisioner GERDQ berbahasa Indonesia $\geq 8.22$ Sedangkan, kriteria eksklusi yaitu pasien yang tidak bersedia dijadikan subjek penelitian, alergi terhadap bahan permen karet, merokok, pengangkatan kelenjar saliva, yang sedang atau pernah terapi radiasi kepala dan leher, penyakit seperti diabetes melitus/HIVIAIDS/ Sjogren syndrom.

Alat dan bahan dalam penelitian ini yaitu gelas ukur (merk GC Saliva Check Buffer Kit), Stopwatch, lembar kuisioner GERDQ, checklist form, informed consent, masker, sarung tangan, permen karet xylitol, parafin wax, tisu, pulpen dan kertas. Hasil data penelitian akan dianalisa mengunakan uji Wilcoxon untuk membandingkan laju aliran saliva terstimulasi antara pengunyahan parafin wax dengan permen karet xylitol.

\section{HASIL PENELITIAN}

Penelitian ini dilakukan pada pasien terindikasi GERD yang bertempat di Poliklinik Penyakit Dalam RSUD dr. Zainoel Abidin Banda Aceh pada tanggal 24 Februari- 24 Maret 2016. Pengambilan sampel pada penelitian ini menggunakan metode non probability sampling dengan teknik purposive sampling. Dengan demikian jumlah keseluruhan subjek dalam penelitian ini berjumlah 17 orang.

Berdasarkan Tabel 1 diketahui bahwa jumlah pasien terindikasi GERD paling banyak berusia 40-59 tahun $(47,1 \%)$ dengan jumlah pasien perempuan $(88,2 \%)$ lebih banyak dibandingkan dengan pasien laki-laki $(11,8)$. Pasien terindikasi GERD paling banyak hanya mengkonsumsi obat GERD (88,2\%) dan sangat sedikit penggunaan obat GERD dengan obat antihipertensi.

Berdasarkan Tabel 2 laju aliran saliva terstimulasi pengunyahan parafin wax pada pasien terindikasi GERD paling banyak dalam kategori rendah $(52,9 \%)$. Sedangkan, laju aliran saliva terstimulasi pengunyahan permen karet xylitol pada pasien yang terindikasi GERD paling banyak dalam kategori normal (76,5\%).

Hasil uji Wilcoxon pada Tabel 3 menunjukkan terdapat perbedaan yang bermakna antara laju aliran saliva terstimulasi pengunyahan parafin wax dengan permen karet xylitol pada pasien terindikasi GERD di RSUD dr. Zainoel Abidin Banda Aceh $(P<0,05)$.

\section{DISKUSI}

Gastroesophageal Reflux Disease (GERD) merupakan suatu keadaan patologis sebagai akibat dari berbaliknya (refluks) kandungan lambung ke esofagus melebihi jumlah normal dan menimbulkan berbagai keluhan. ${ }^{1}$ Saliva mempunyai peran terhadap perkembangan GERD. Pembersihan asam di esofagus dapat dilakukan dengan penelanan saliva untuk melindungi dinding esofagus dari destruksi asam. ${ }^{15,23}$ Refluks asam yang melebihi jumlah normal dan frekuensi refluks yang sering menyebabkan ketidakmampuan saliva dalam 
pembersihan asam sehingga saliva terganggu

secara kuantitas dan kualitas..$^{21,24}$

Berdasarkan hasil penelitian terhadap 17 orang pasien terindikasi GERD di Poliklinik Penyakit Dalam RSUD dr. Zainoel Abidin
Banda Aceh (Tabel 2) diketahui laju aliran saliva terstimulasi pengunyahan parafin wax paling banyak berada pada kondisi di bawah normal yaitu rendah sebesar $52,9 \%$. Hasil ini sejalan dengan penelitian Filipi dkk (2011) juga

Tabel 1. Distribusi Frekuensi Subjek Penelitian Berdasarkan Usia, Jenis Kelamin dan Konsumsi Obat.

\begin{tabular}{|c|c|c|}
\hline Variabel & Jumlah Subjek & Persentase (\%) \\
\hline \multicolumn{3}{|l|}{ Usia (Tahun) } \\
\hline $20-39$ & 4 & 23,5 \\
\hline $40-59$ & 8 & 47,1 \\
\hline $60-69$ & 5 & 29,4 \\
\hline \multicolumn{3}{|l|}{ Jenis Kelamin } \\
\hline Laki-laki & 2 & 11,8 \\
\hline Perempuan & 15 & 88,2 \\
\hline \multicolumn{3}{|l|}{ Konsumsi Obat-obatan } \\
\hline Hanya menggunakan obat GERD & 15 & 88,2 \\
\hline Obat GERD + obat antihipertensi & 2 & 11,8 \\
\hline Obat GERD + obat antihistamin & 0 & 0 \\
\hline Obat GERD + obat diuretik & 0 & 0 \\
\hline $\begin{array}{l}\text { Obat GERD + menggunakan } 2 \text { obat } \\
\text { (antihipertensi,antihistamin, } \\
\text { secara bersamaan }\end{array}$ & 0 & 0 \\
\hline
\end{tabular}

Tabel 2. Tabulasi Silang Laju Aliran Saliva Terstimulasi Pengunyahan Parafin Wax dan Permen Karet Xylitol pada Pasien yang Terindikasi GERD

\begin{tabular}{lllll}
\hline \multirow{2}{*}{ Laju Aliran Saliva } & \multicolumn{2}{c}{ Parafin $\boldsymbol{w a x}$} & \multicolumn{2}{c}{ Permen karet $\boldsymbol{x y l i t o l}$} \\
\cline { 2 - 5 } & $\mathbf{N}$ & $\mathbf{0}$ & $\mathbf{N}$ & $\mathbf{\%}$ \\
\hline Tinggi & 0 & 0 & 3 & 17,6 \\
Normal & 6 & 35,3 & 13 & 76,5 \\
Rendah & 9 & 52,9 & 1 & 5,9 \\
Sangat Rendah & 2 & 11,8 & 0 & 0 \\
\hline \multicolumn{1}{c}{ Total } & 17 & 100 & 17 & 100 \\
\hline
\end{tabular}

Keterangan: $\mathbf{N}=$ Jumlah Pasien, $\%=$ Persentase

Tabel 3. Hasil Uji Wilcoxon Laju Aliran Saliva Terstimulasi antara Pengunyahan Parafin Wax dengan Permen Karet Xylitol pada Pasien Terindikasi GERD

\section{Variabel}

Perbedaan laju aliran aliva terstimulasi antara pengunyahan parafin wax dengan permen karet $x y l i t o l$ pada pasien terindikasi GERD

\section{P-value}

0,001 
menyatakan laju aliran saliva yang terstimulasi pada pasien GERD lebih rendah dibandingkan dengan orang normal lainnya. ${ }^{25}$ Perbedaan diperlihatkan pada laju aliran saliva terstimulasi pengunyahan permen karet xylitol paling banyak berada pada kondisi normal sebesar 76,5 \% (Tabel 2). Penelitian Polland dkk (2003) menyatakan bahwa pengunyahan permen karet xylitol dapat dengan cepat meningkatkan laju aliran saliva karena merupakan dua kombinasi stimulus yaitu stimulus rasa dan mekanis. ${ }^{18}$

Penelitian Soderling dkk memperkuat dengan membandingkan antara laju aliran saliva terstimulasi pengunyahan parafin wax, xylitol, sorbitol, fruktosa dan sukrosa dan didapatkan bahwa laju aliran saliva terstimulasi permen karet tanpa rasa lebih rendah dibandingkan dengan laju aliran saliva terstimulasi permen karet dengan rasa seperti xylitol, sorbitol, fruktosa dan sukrosa. ${ }^{26}$

Pemberian permen karet xylitol 3 sampai 5 kali dengan dosis 6-10 gram perhari dan dikunyah selama 5 menit dapat memicu mineralisasi dengan meningkatan laju aliran saliva. ${ }^{27,28}$ Pengunyahan permen karet xylitol juga direkomendasikan untuk penderita GERD yang mempunyai penurunan saliva dengan mengunyah permen karet xylitol 5 menit setelah makan dan setelah refluks untuk menjaga kualitas dan kuantitas saliva ${ }^{19,21}$ sehingga dapat menjalankan fungsinya dengan optimal untuk melindungi dinding esofagus dari bahan asam akibat relaksasi sementara dari sfingter esofagus bawah dengan cara penelanan saliva. ${ }^{15}$

\section{KESIMPULAN}

Berdasarkan penelitian yang telah dilakukan, dapat disimpulkan bahwa terdapat perbedaan yang bermakna antara laju aliran saliva terstimulasi pengunyahan parafin wax dengan pengunyahan permen karet xylitol pada pasien terindikasi GERD di RSUD dr. Zainoel Abidin Banda Aceh $(P<0,05)$.

\section{DAFTAR PUSTAKA}

1. Vakil N, van Zanten SV, Kahrilas P, Dent J, Jones $R$. The Montreal definition and classification of gastroesophageal reflux disease: a global evidence-based consensus. American Journal of Gastroenterol 2006;101:1900-43

2. Guarner, Lazaro, Gascon, Royo, Eximan, Herrero. Map of digastive disorder and disease (MDD). World Gastroentrology Organization 2008; 9-12

3. Jung HK. Epidemiology of Gastroesophageal Reflux Disease in Asia: A Systematic Review. Journal of Neurogastroenterology and Motility 2011;17(1): 1-14

4. Rosaida MS, Goh KL. Gastroesophageal reflux disease, reflux esophagitis and non erosive disease in a multiracial asian population: a prospective, endoscopy based study. European Journal Gastroenterol Hepatol 2004; 16:495-501

5. Sarigih RH, Rey I. FSSG Scale System in Comparison with GERD Quetionnaires in Predicting Endoscopic Finding with Reflux Esophagitis. The Indonesian Journal of Gastroenterology, Hepatology and Digestive Endoscopy 2012; 14(3): 136-140

6. Persatuan Dokter IImu Spesialis Penyakit Dalam Indonesia. 2009. Buku Ajar IImu Penyakit Dalam. Jakarta: Interna Publishing;480-492

7. Naik RD, Vaezi MF. Extra-Esophageal Manifestation of GERD: Who Responds to GERD Therapy?. Curr Gastroenterol Rep 2013; 13: 318319

8. Pace F, Pallotta S, Tonini M, Vakil N, Porro GB. Systematic review: gastro-oesophageal reflux disease and dental lesions. Alimentary Pharmacology Therapeutics 2008;27:1179-86.

9. Pindborg JJ. 1970. Chemical and physical injuries. In: Pindborg JJ, ed. Pathology of the Dental Hard Tissues. Philadelphia: WB Saunders 312-25.

10. Ranjitkar S, Kaldonis JA, Smales R. Gastroesophageal Reflux Disease and Tooth Erosion. International Journal of Dentistry 2011: 1-11

11. Hara HT, Carvalho JC, Zero DT. Causes of Dental Erosion: Extrinsic Factors. In: Dental Erosion and Its Clinical Management. San Antonio: Springer 2015; 69-83

12. Zero DT. Etiology of dental erosion - extrinsic factors. European Journal Oral Science 1996;104: $162-177$ 
13. Roberts MW, Li SH. Oral findings in anorexia nervosa and bulimia nervosa: a study of 47 cases. Journal American Dental Association 1987;115: 470-410

14. Scaramucci T, Carvalho JC, Hara AT, Zero DT. Causes of Dental Erosion: Intrinsic Factors. In: Dental Erosion and Its Clinical Management. San Antonio: Springer 2015; 35-59

15. Ekstrom J, Khosravani N, Castagnola M, Messana I. Saliva and the Control of its Secretion. Verlag Berlin Heidelberg 2012: 19- 47

16. Vigna PD, Trindade AM, Naval MA, dkk. Saliva Composition and Functions: A Comprehensive Review. The Journal of Contemporary Dental Practice 2008; 9(3): 1-11

17. Greenberg MS, Glick M. 2003. Burket's Oral medicine diagnosis and Treatment 10 th ed. New York: BC Decker Inc. 346-348

18. Polland KE, Higgins F, Orchardson R. Salivary flow rate and $\mathrm{pH}$ during prolonged gum chewing in humans. Journal of Oral Rehabilitation 2003;30(9):861-865

19. Patel A, Amaechi BT, Brady C. Prevention and Control of Dental Erosion: Gastroesophageal Reflux Disease Management 2015: 203-224

20. Yosikawa H, Furuta K, Ueno M. Oral Symtoms Including Dental Erosion in Gastroesophageal Reflux Disease are Associated with Decreased Salivary Flow Volume and Swallowing Function. Journal Gastroenterohepatology 2012; 47: 412-
420

21. Dundar A, Sengun A. Dental Approach to Erosive Tooth Wear in Gastroesophageal Reflux Disease. African Health Sciences 2014; 14(2): p. 481-486

22. Jones R, Junghard O, Dent J. Development of the GerdQ, a tool for the diagnosis and management of gastro-oesophageal reflux disease in primary care. Alimentary Pharmacology Therapeutics 2009;30:1030-8.

23. Gutyon AC, Hall JE. 2006. Textbook of Medical Physiology. 11th ed. Jakarta: Elsevier: 1016-1018

24. Moazzez R, Barlett D, Anggiansah A. Dental erosion, gastro-oesophageal reflux disease: how related?. Journal of Dentistry 2004; 32: 489-494

25. Filipi K, Halacknova Z, Filipi V. Oral health status, salivary factors and microbial analysis in patients with active gastro-esophageal reflux disease. International Dental Journal 2011;61:231-237

26. Sonderling E, Rekola M, Makinen KK, Scheinin A. Turku sugar studies XXI: xylitol, sorbitol, fructose, and sucrose induced physico chemical change in saliva. Acta Odontologica Scandinavica 2015;34:397-403

27. Riedy CA, Milgrom P, Rothen M. A surrogate method for concentrations of xylitol-containing product. BMC Oral Health 2008; 8(5): 1-8

28. Sonderling E, Hirvonen A, Karjalainen S. The effect of xylitol on the composition of the oral flora: a pilot study. European Journal of Dentistry 2011; 5: $24-31$ 